\title{
A Comparative Study Job Satisfaction among the Working Men in Industrial Area
}

\author{
Dr. Bhartiben Vyas
}

\section{ABSTRACT:}

The present study is an attempt to measure overall job satisfaction of industrial workers, to identify some determinants of job satisfaction, and to evaluate the perceived importance of job facets to their overall job satisfaction. The term job satisfaction refers to favorable or unfavorable feelings and emotion of the employees towards their own work. It refers to the satisfaction of the employee in his own profession. Job satisfaction is the result of various attitudes possessed by an employee towards his job. These attitudes may be related to job factors such as wage, job security, job environment, nature of work, opportunity for promotion, prompt removal of grievance, opportunity for participation in decision making and other fringe benefits. Life is itself a process of adjustment. If anyone wants satisfaction in life, then they have to adjust with their environment. The total sample consisted of 240 men from different industrial Area in south Gujarat. The sample was selected from randomly. Job satisfaction scale By Brefild Roth (Gujarati Format By Parikh) developed were used for data collection. $2 \times 3 \times 2$ factorial design was used.

Keywords: Job Satisfaction, Industrial Area

\section{INTRODUCTION:}

Job satisfaction is the collection of tasks and responsibilities regularly assigned to one person, while a job is a group of positions, which involves essentially the same duties, responsibility, skill and knowledge". Job satisfaction has some relation with the mental health of the people. It spreads the goodwill of the organization. Job satisfaction reduces absenteeism, labour turnover and accidents. Job satisfaction increases employee's morale, productivity, etc. Job satisfaction creates innovative ideas among the employees. Individuals may become more loyal towards the organization Employees will be more satisfied if they get what they expected, job satisfaction relates to inner feelings of workers. Naturally it is the satisfied worker who shows the maximum effectiveness and efficiency in his work. Most people generalize that workers are concerned more about pay rather than other factors which also affects their level of satisfaction, such as canteen facilities, bonus, working conditions, etc. these conditions are less significant when compared to pay.

${ }^{1}$ Associate Professor, (Psychology), M. T. B. Arts college, Surat

(C) 2015, B Vyas; licensee IJIP. This is an Open Access Research distributed under the terms of the Creative Commons Attribution License (http://creativecommons.org/licenses/by/2.0), which permits unrestricted use, distribution, and reproduction in any Medium, provided the original work is properly cited. 


\section{STATEMENT OF THE PROBLEM}

Employees play are important role, so employee's satisfaction is a very essential one, hence there arises a need to study the job satisfaction of paper mill employees,

Job satisfaction is an internal component of work climate. While working in organizations, people develop a set of attitudes about the work, supervision, coworkers, working conditions, and so on. This set of attitudes is referred to as job satisfaction. The term satisfaction generally implies the fulfillment acquired by experiencing various job activities.

Man works not only for money alone but also to satisfy his higher order needs, needs to be recognized, to be appreciated and to feel a sense of achievement in whatever one does. Employees in different establishment view their respective worlds of work in different perspective for various reasons. They may differ in their respective personalities, need, and social background or in demographic factors. But the facts remains that they tend to act or behave in their peculiar way on the background of their perceptions.

A person joins an organization with certain hopes, expectation, drives and needs which affects his performance. Sometimes it seems to be difficult to ascertain. This varies from person to person. However it is highly useful to understand as to how the need create tension, which stimulates the effort to perform and how effectively performance brings satisfaction.

The workers' satisfaction in work is greatly affected by the physical condition in which the work is done, the way in which the flow of work is organized and the equipments and materials with which the work is done.

Hoppock (cited by Ganguli 1964) who has made pioneering studies on job satisfaction mentioned the following six factors as major determinants of job satisfaction.

i) The manner in which the individual reacts to unpleasant situation.

ii) The facility with which he adjust himself to other person.

iii) This relative status in the social and economic groups with which he identifies himself.

iv) The nature of work in relation to the man's abilities interests and training.

v) Security

vi) Loyalty.

Richard Wynn (1966) has emphasized the following factors influencing satisfaction in the job.
i) Intrinsic value of work
ii) Security of life
iii) The right to participate
iv) Recognition and approval
v) Human treatment
vi) Self expression 
There are three important dimensions to job- satisfaction:

1) Job- satisfaction refers to one $e^{e e}$ feeling towards one es job. It can only be inferred but not seen.

2) Job satisfaction is often determined by how well outcomes meet or exceed expectations. Satisfaction in one ${ }^{\text {ee }}$ job means increased commitment in the fulfillment of formal requirements. There is greater willingness to invest personal energy and time in job performance.

3) The terms job-satisfaction and job attitudes are typically used interchangeably. Both refer to effective orientations on the part of individuals towards their work roles, which they are presently occupying.

Present study is an attempt to trace out the level of job satisfaction of the working men in industrial Area and the significant difference among the working men engaged in different professions in respect of their job satisfaction has also been studied.

\section{RESEARCH PROBLEM}

Presented research study's problem : A Comparative study Job satisfaction among the working men in industrial Area

\section{RESEARCH PURPOSE}

The purpose of all this research was to look at different industrial Aria and contentment to living on campus. Researchers interested in this area have wanted to determine how well working men fit into the lifestyles and Job satisfaction on campuses.

\section{REVIEW OF LITERATURE}

The study of job satisfaction is a topic of wide interest to both people who work in organizations and people who study them. Job satisfaction has been closely related with many organizational phenomena such as motivation, performance, leadership, attitude, conflict, moral etc. Researchers have attempted to identify the various components of job satisfaction, measure the relative importance of each component of job satisfaction and examine what effects these components have on employees' productivity.

1. Keith Davis, "Job satisfaction is defined as "Favorableness or unfavorableness with which the employees view their work and results when there is a fit between job characteristic and wants of the employees"

2. Stephen P. Robbins: Job satisfaction as the "difference between the amount of rewards the workers receive and the amount they believe they should receive".

3. Further he says, "Job satisfaction is an individual general attitude towards his or her job". 
4. C. B. Mamoria explains: "job satisfaction is the collection of tasks and responsibilities regularly assigned to one person while a job is a group of positions, which involves essentially the same duties, responsibility, skill and knowledge".

5. In Locke words, "Job satisfaction is defined as a pleasurable or positive emotional state resulting from the appraisal of one's job or job experience".

6. Robert L. Kahn reveals, "Job satisfaction does seem to reduce absence, turnover and perhaps accident rates"

7. Robert A. Baron: Job satisfaction is the positive or negative attitude held by individuals toward their job

8. Further he says, "Job satisfaction is defined as individual cognitive, affective and evaluative reaction towards their job".

9. Spector (1997) refers to job satisfaction in terms of how people feel about their jobs and different aspects of their jobs.

10. Ellickson and Logsdon (2002) support this view by defining job satisfaction as the extent to which employees like their work.

\section{OBJECTIVES}

In this research paper Independent variable are Educational Category, Age and Type of salary \& dependent variables is Job satisfaction. Following main objective are kept in this research paper.

1. To study the Job satisfaction of working men in surat industrial Aria.

2. To study the effect of Category on Job satisfaction.

3. To study the effect of Age on Job satisfaction.

4. To study the effect of City on Job satisfaction.

\section{LIMITATIONS OF THE STUDY}

- The survey is subjected to the bias and prejudices of the respondents. Hence $100 \%$ accuracy can't be assured.

- The researcher was carried out in a short span of time, where in the researcher could not widen the study.

- The study could not be generalized due to the fact that researcher adapted personal interview method.

\section{VARIABLES OF THE STUDY}

1. DEPENDENT VARIABLES :- Job satisfaction as a dependent variable

2. INDEPENDENT VARIABLES :- Category, Age, Type Of city

\section{Typey of Category :-}

1. Open category

2. SC/ST/Baxi category 


\section{Type Of Age :-}

1. Age between 35 to 45 years,

2. Age between 46 to 55 years,

3. Above 56 years

\section{Type of City :-}

1. Surat city

2. Bharuch city

\section{HYPOTHESES-}

1. There will be no significant difference between category ( Open and SC/ST/BAXI ) in relation to Job satisfaction.

2. There will be no significant difference between type of Age ( 35 to 45, 46 to 55, Above 56 years ) in relation to Job satisfaction.

3. There will be no significant difference between type of City (Surat and Bharuch city) in relation to Job satisfaction.

4. There will be no significant difference between category \& type of Age in relation to Job satisfaction.

5. There will be no significant difference between type of Age \& type of City in relation to Job satisfaction.

6. There will be no significant difference between type of City and type of category in relation to Job satisfaction.

7. There will be no significant difference between Category, Age, and Type of City in relation to Job satisfaction.

\section{TOOLS-}

There are 18 statement of Job satisfaction questioner developed by Brefild Roth (1985) (Gujarati Format By Parikh). 9 affirmative and 9 negative items. Five point scale rate is use in this questioner for affirmative word 5,4,3,2, and 1 score is give while for negative word the opposite number 1,2,3,4 and 5 score given. affirmative statement no 1, 2, 5, 7, 9, 12, 13, 16, and 18 also negative statement no $3,4,6,8,10,11,14,15$, and 17 . This score range is from 18 to 90. The test retest reliability of the scale is $0.71(\mathrm{~N}=50)$. 


\section{RESEARCH DESIGN:}

$2 \times 3 \times 2$ factorial research design is for used the research.

Total : 240

\begin{tabular}{|c|c|c|c|c|c|c|}
\hline \multirow{2}{*}{ Variable } & \multicolumn{3}{|c|}{ open category } & \multicolumn{3}{c|}{ SC/ST/Baxi } \\
\cline { 2 - 7 } & $\begin{array}{c}\text { Age } \\
\text { between } \\
\mathbf{3 5} \text { to 45 } \\
\text { years }\end{array}$ & $\begin{array}{c}\text { Age } \\
\text { between } \\
\mathbf{4 6} \text { to 55 } \\
\text { years }\end{array}$ & $\begin{array}{c}\text { Age above } \\
\mathbf{5 6} \text { years }\end{array}$ & $\begin{array}{c}\text { Age } \\
\text { between } \\
\mathbf{3 5} \text { to 45 } \\
\text { years }\end{array}$ & $\begin{array}{c}\text { Age } \\
\text { between } \\
\mathbf{4 6} \text { to 55 } \\
\text { years }\end{array}$ & $\begin{array}{c}\text { Age above } \\
\mathbf{5 6} \text { years }\end{array}$ \\
\hline Surat city & 20 & 20 & 20 & 20 & 20 & 20 \\
\hline $\begin{array}{c}\text { Bharuch } \\
\text { city }\end{array}$ & 20 & 20 & 20 & 20 & 20 & 20 \\
\hline Total & 40 & 40 & 40 & 40 & 40 & 40 \\
\hline
\end{tabular}

\section{SAMPLE}

To select the sample Type of category, Type of Age, Type of City were considered as per independent variable taken in this research. Stratified random sampling method was employed of select the unit of sample. Total sample of the present investigation comprised 240 adolescences, in which 120 men were from open category and $120 \mathrm{SC} / \mathrm{ST} / \mathrm{Baxi}$ category. Both groups entail equal number of Age between 35 to 45, 46 to 55, and Age above 56 years. Again each group was divided by equal number of Surat city and Bharuch City. Thus total sample includes 12th components as shown in the following table.

\section{STATISTICAL ANALYSIS}

The data were analyzed as follows; The mean with graphical representation for Type of Category (open and SC/ST/Baxi category), Type Of Age ( Age between 35 to 45 years, 46 to 55 years, age above 56 years ) and Type of City (Surat city and Bharuch city) on working men Job satisfaction was analyzed. A $2 \times 3 \times 2$ factorial design was subjected to adequate of statistical analysis viz. technique of Analysis of variance (ANOVA) in order to examine the roll of main variables and to industrial Aria their main as well as interaction effects subsequently on working men's Job satisfaction.

\section{RESULT AND INTERPRETATION}

\section{Dependent Variable : Job satisfaction}

The aim of the present study was to investigate the effect of category, Type of Age, Type of City variable on Job satisfaction. 
Table 1 ANOVA for Job satisfaction in context of category, Type of Age, Type of City variable :

\begin{tabular}{|c|r|r|r|r|r|}
\hline $\begin{array}{c}\text { SOURCE } \\
\text { of variance }\end{array}$ & $\begin{array}{c}\text { SUM OF } \\
\text { SQUARE }\end{array}$ & DF & $\begin{array}{r}\text { MEAN SUM } \\
\text { OF SQUARE }\end{array}$ & F & $\begin{array}{c}\text { LEVEL OF } \\
\text { SIG. }\end{array}$ \\
\hline \multicolumn{7}{|c|}{ Main effects } \\
\hline SSA & 1233.07 & 1 & 1233.07 & 15.38 & 0.1 \\
\hline SSB & 145.16 & 2 & 72.58 & 0.91 & N.S \\
\hline SSC & 3038.817 & 1 & 3038.82 & 37.9 & 0.1 \\
\hline \multicolumn{7}{|c|}{ Interaction effects } \\
\hline SSAXB & 237.7583 & 2 & 118.88 & 1.48 & N.S \\
\hline SSBXC & 25.15833 & 2 & 12.58 & 0.16 & N.S \\
\hline SSCXA & 160.0667 & 1 & 160.07 & 2.00 & N.S \\
\hline SSAXBXC & 105.7583 & 2 & 52.88 & 0.66 & N.S \\
\hline SSW & 18277.8 & 228 & 80.17 & & \\
\hline SST & 23223.58 & 239 & & & \\
\hline
\end{tabular}

Significance Level

$\mathrm{N}$

0.05

0.01
( Df1) 228
3.87
6.72
( Df2) 228
3.03
4.68

Table $2 \mathrm{~F}$ value and mean for Category variable : A

\begin{tabular}{|c|c|c|c|c|}
\hline Category & $\mathrm{N}$ & Mean & F & Sig. level \\
\hline A1 & 120 & 58.78 & \multirow{2}{*}{15.38} & 0.1 \\
\hline A2 & 120 & 63.31 & & \\
\hline
\end{tabular}

Table $3 \mathrm{~F}$ value and mean for Type of Age variable : B

\begin{tabular}{|c|c|c|c|c|}
\hline Type Of Age & $\mathrm{N}$ & Mean & F & Sig. level \\
\hline B1 & 80 & 60.58 & & \multirow{2}{*}{0.91} \\
B2 & 80 & 60.41 & N.S \\
\hline B2 & 80 & 62.14 & & \\
\hline
\end{tabular}

Table $4 \mathrm{~F}$ value and mean for Type of salary variable : $\mathrm{C}$

\begin{tabular}{|c|c|c|c|c|}
\hline Type of City & $\mathrm{N}$ & Mean & F & Sig. level \\
\hline $\mathrm{C} 1$ & 120 & 57.48 & \multirow{2}{*}{37.9} & 0.1 \\
\hline $\mathrm{C} 2$ & 120 & 64.6 & & \\
\hline
\end{tabular}


Table $5 \mathrm{~F}$ value and mean for Category and Type of Age variable : AXB

\begin{tabular}{|c|c|c|c|c|}
\hline Variable & & & & \\
\hline Type Of Age & A1 & $\mathrm{A} 2$ & $\mathrm{~F}$ & Sig. level \\
\hline B1 & 57.38 & 63.78 & \multirow{6}{*}{1.48} & \multirow{6}{*}{ N.S } \\
\hline $\mathrm{N}$ & 40 & 40 & & \\
\hline B2 & 57.7 & 63.13 & & \\
\hline $\mathrm{N}$ & 40 & 40 & & \\
\hline B3 & 61.25 & 63.03 & & \\
\hline $\mathrm{N}$ & 40 & 40 & & \\
\hline
\end{tabular}

Table $6 \mathrm{~F}$ value and mean for Type of Age and Type of City variable : BXC

\begin{tabular}{|c|c|c|c|c|c|}
\hline Variable & \multicolumn{3}{|c|}{ Type Of Age } & \\
\cline { 1 - 4 } Type of City & B1 & B2 & B3 & F & \multirow{2}{*}{0.16} \\
\cline { 1 - 3 } C1 & 56.65 & 56.8 & 59 & \multirow{2}{*}{ N.S level } \\
\hline N & 40 & 40 & 40 & & \\
\hline C2 & 64.5 & 64.03 & 65.28 & & \\
\hline
\end{tabular}

Table $7 \mathrm{~F}$ value and mean for Type of City and type of Category variable :CXA

\begin{tabular}{|c|c|c|c|c|}
\hline \multirow{2}{*}{ Variable } & \multicolumn{2}{|c|}{ Type Of Category } & \\
\hline Type of City & A1 & A2 & F & Sig. level \\
\hline C1 & 54.4 & 60.57 & \multirow{2}{*}{2.00} & \multirow{2}{*}{ N.S } \\
\hline N & 60 & 60 & & \\
\hline C2 & 63.15 & 66.05 & & \\
\hline
\end{tabular}

Table $8 \mathrm{~F}$ value and mean for Category, Type of Age and Type of City variable :AXBXC

\begin{tabular}{|c|c|c|c|c|c|c|c|c|}
\hline \multirow{2}{*}{ Variable } & \multicolumn{3}{|c|}{ A1 } & \multicolumn{3}{c|}{ A2 } & & \\
\cline { 2 - 9 } & B1 & B2 & B3 & B1 & B2 & B3 & F & $\begin{array}{c}\text { Sig. } \\
\text { level }\end{array}$ \\
\hline C1 & 53.5 & 53.15 & 56.55 & 59.8 & 60.45 & 61.45 & & \\
\cline { 1 - 8 } N & 20 & 20 & 20 & 20 & 20 & 20 & \multirow{2}{*}{0.66} & \multirow{2}{*}{ N.S } \\
\hline C2 & 61.25 & 62.25 & 65.95 & 67.75 & 65.8 & 64.6 & & \\
\hline N & 20 & 20 & 20 & 20 & 20 & 20 & & \\
\hline
\end{tabular}




\section{MAIN EFFECT :-}

The result reveal at that category, Type of Age, Type of City variables are all significant at level of 0.01 .

Table - 2 shows $\mathrm{F}$ value and mean for Category variable. In which, mean for open category workers 58.76 and for SC/ST/Baxi category workers is 63.31 and F value is 15.38 which is significant at the level of 0.01 . Thus, there is a significant difference in Job satisfaction level of among open and SC/ST/Baxi category workers. In which SC/ST/Baxi category workers have highest mean than other groups, says that they have more good Job satisfaction level than other group.

Table - 3 shows $\mathrm{F}$ value and mean for Type of Age variable. In which, mean for Age between 35 to 45 years workers is 60.58, Age between 46 to 55 years age is 60.41 and Age above 56 years is 62.13 and $F$ value is 0.91 which is not significant at the level of 0.01 . So, there is no significant difference in Job satisfaction level among Age between 35 to 45 years, 46 to 55 years, and above 56 years. In which Age above 56 years worker have highest mean than other groups, says that they have more good Job satisfaction level than the other group.

Then, table -4 shows $\mathrm{F}$ value and mean for type of City variable. In which, mean for Surat city is 57.48 and for Bharuch City is 64.6 and $F$ value is 37.9 which is significant at the level of 0.01 . Therefore, there is a significant difference in Job satisfaction level Surat city and Bharuch City. In which Bharuch City workers have highest mean than other groups, says that they have more good Job satisfaction level than the other group.

\section{INTERACTIONAL EFFECT :-}

Table -5 shows F value and mean of A x B for interactional effect of category and type of Age variable on Job satisfaction. There were six group in which mean for Age between 35 to 45 years open category workers is 57.38, Age between 46 to 55 years open category workers is 57.7, Age above 56 year open category workers is 61.25 , Age between 35 to 45 years SC/ST/Baxi category worker is 63.78, Age between 46 to 55 years SC/ST/Baxi category worker is 63.13 and Age above 56 year up SC/ST/Baxi category men workers is 63.03. Their F value is 1.48 which is not significant at the level of 0.01 . In which Age between 35 to 45 years SC/ST/Baxi category workers have highest mean than other five groups. It means Age between 35 to 45 years SC/ST/Baxi category workers have more good Job satisfaction level than the other groups.

Table - 6 shows F value and mean B x C for interactional effect of Type of age and City variable on Job satisfaction. There were six groups in which mean for Surat city in Age between 35 to 45 years is 56.65, Bharuch city in Age between 35 to 45 years is 64.5, surat city in Age between 46 to 55 years is 56.8, Bharuch city in Age between 46 to 55 years is 64.03, surat city in Age above 56 years is 59 and Bharuch city in Age 56 years is 65.28. F value of these group is 0.16 which is not significant. It shows that there is significant difference in any of these five group in Job 
satisfaction. In which Bharuch city in Age 56 years have highest mean than other groups, say that they have more good Job satisfaction level than the other group.

Table - 7 shows F value and mean $\mathrm{C}$ x A for interactional effect of City and type of category variable on Job satisfaction. There were four groups in which mean for Surat city in open category workers is 54.4 , Bharuch city open category workers is 63.15 , Surat city ST/SC/Baxi category workers is 60.57 and Bharuch city ST/SC/Baxi category worker is 66.05 . F value for these group is 2.00 which is not significant at the level of 0.01 . In which Bharuch city ST/SC/Baxi category workers have highest mean than all other groups, says that they have more good Job satisfaction level than the other group.

Table - 8 shows F value and mean A x B x C for interactional effect of category, type of Age and type of city variable on Job satisfaction. There were twelve group. F value of these groups is 0.66 which is not significant at the level of 0.01. In these groups, SC/ST/Baxi Age between 35 to 45 years in Bharuch city have highest mean than other eleven groups, says that they have more good Job satisfaction level than the other group.

\section{CONCLUSIONS :}

1. There will be significant difference between category ( Open and SC/ST/BAXI ) in relation to Job satisfaction.

2. There will be no significant difference between type of Age ( 35 to 45, 46 to 55, 56 up ) in relation to Job satisfaction.

3. There will be significant difference between type of City (Surat and Bharuch city) in relation to Job satisfaction.

4. There will be no significant difference between category \& type of Age in relation to Job satisfaction.

5. There will be no significant difference between type of Age \& type of City in relation to Job satisfaction.

6. There will be no significant difference between type of City and type of category in relation to Job satisfaction.

7. There will be no significant difference between Category, Age, and Type of City in relation to Job satisfaction.

\section{RECOMMENDATION}

Opportunities for future study have emerged as a result of this study. In addition to overcoming the limitations of data gathering, additional research is needed to observe the relationships between job satisfaction and work conditions, pay and promotion, fairness, job security, relationship with supervisor and co-workers. The limitations have contributed to the lack of arriving at many strongly statistically proven findings and conclusions. For future research the following suggestions should be considered: 
1) It is suggested that for future research a proportionate stratified random sample be used to compare several public sector institutions using a larger sample.

2) The research is needed to further investigate the potential relationships and affects these variables and other extraneous variables, such as role ambiguity, job level, contingent rewards and co-work have on job satisfaction.

3) Qualitative investigators must conduct research regarding the job satisfaction of pharmaceuticals companies. This research method will provide a different perspective of employees, job satisfaction and contribute a more in-depth understanding of how employees view their job.

\section{REFERENCES-}

1. AL-Hussami M (2008). A Study of nurses' job satisfaction: The relationship to organizational commitment, perceived organizational support, transactional leadership, transformational leadership, and level of education. Eur. J. Sci. Res., 22(2): 286-295.

2. Asthana, Bipin : Measurement and Evaluation in Psychology and Education, Vinod Pustak Mandir, Agra-2.

3. Buch, M.B. (Ed) (1974) : A Survey of Research in Education. Baroda: Centre of Advanced Study in Education and Psychology, M.S. University of Baroda.

4. E. A Locke (1980)The Nature and Causes of Job Satisfaction. M.D Dunnette (Ed.), Handbook of Industrial and Organizational Psychology, Chicago, Rand McNally. pp.1297-1349

5. Ferguson, G.A. (1976) : Statistical Analysis in Psychology and Education, New York, McGraw Hill.

6. Indian psychological Review, 52,74-78 Broota, K.D(2000), Experimental Design in behavioral research, New age.

7. Garret, H.E. (1968). General Psychology((Indian reprint). New Delhi: Eurasia Pblushing House.

8. Garret,Henry,E (1981) : Statistic in Psychology and Education, Bombay: Vikils, Feffer and Simsons Ltd.

9. Griffin MA, Patterson MG, West MA (2001). Job satisfaction and team work: the role of supervisor support. J. Organ. Behav., 22: 537-550.

10. Jain, Mahendra, Kumar (2006) : Job Satisfaction of Teachers. New Delhi, Discovery.

11. Koul, L. (1997) : Methodology of Educational Research. New Delhi: Vikash Publishing House Pvt. Ltd.

12. Poonam Singh (2007) : Effect of Stress on Job Satisfaction and Work-values among teachers. New Delhi, Adhyan. 
13. Panda, B.B. (1996) : A Comparative study of the Attitude towards Teaching Profession and Job Satisfaction of College Teachers of Assam and Orissa, Ph.D. Thesis, Gauhati University.

14. Reddy, G. Lokanandha (2007) : Special Education Teachers: Occupational Stress, Professional Burnout and Job Satisfaction. New Delhi, Discovery.

15. Tharacon, P.N.O. (1992) : Occupational Stress and Job Satisfaction among Working Women, Journal of Indian Academy of Applied Psychology, xviii (i-iii), (P. 37-40). 